\title{
SUSTAINABLE BEEF CATTLE BUSINESS IN INTEGRATION SYSTEM WITH FOOD PLANT IN GORONTALO DISTRICT
}

\author{
RITA SUSANA MARWATY ${ }^{1}$, M. NUR IHSAN ${ }^{2}$, UMI WISAPTININGSIH ${ }^{3}$ \& S. SUYADI ${ }^{4}$ * \\ ${ }^{I}$ Postgraduate Student of the Faculty of Animal Husbandry, Brawijaya University Malang, Indonesia \\ ${ }^{2,3,4}$ Lecturer at the Faculty of Animal Husbandry, Universitas Brawijaya Malang, Indonesia
}

\begin{abstract}
Gorontalo District is one of the districts in Gorontalo Province, which can develop a beef cattle business. This study aimed to determine the beef cattle business's sustainability in the integrated system with food crops. This research was conducted in three sub-districts and six villages in Gorontalo District from April to June 2018 using a survey method. Primary data were collected through interviews, focus group discussions, and questionnaires for 100 respondents, while secondary data collected through documentation reports from related agencies and previous research. Data analysis used the Rap-SISPOTTA modified sustainability analysis method. Measurement sustainability based on economic dimensions, environmental dimensions, technical dimensions, institutional dimensions, and social dimensions and then analyzed by Multi-Dimensional Scaling using Exel for Rap-SISPOTTA. Wherewith this application, a feasibility and significance test is carried out with sustainability analysis, and simulation analysis of the sustainability model. The results show that each dimension's performance attributes are mapped into two reference points: bad points and good points, and the performance level is divided into four categories. The current resources owned by farmers make it possible to run an integrated crop and livestock business. The results showed that dimension's performance attributes mapped into two reference points: bad points and good points, and the performance level was divided into four categories. The current resources owned by farmers make it possible to run an integrated crop and livestock business. The results show that each dimension's performance attributes are mapped into two reference points: bad points and good points, and the performance level is divided into four categories. The current resources owned by farmers make it possible to run an integrated crop and livestock business.
\end{abstract}

KEYWORDS: Beef Cattle Business, Food Crop Integration \& Sustainable

Received: Jan 20 2021; Accepted: Feb 10, 2021; Published: Mar 10, 2021; Paper Id.: IJMPERDAPR202119

\section{INTRODUCTION}

Gorontalo District is one of the districts in Gorontalo Province that still has land support for potential livestock development. Gorontalo District has an area of $\pm 1,750.83 \mathrm{~km} 2$, consisting of 11,271 ha of irrigated land, 2,704 ha of rain fed land, and 355,988 people $34.22 \%$ of the total population of Gorontalo Province. The Gorontalo Regency has 19 sub-districts; farmers agricultural activities with rice production 178,607 tons per year, 417,516 tons of corn per year, 80 tons of cassava per year, 223 tons of soybeans per year, peanuts 37 tonnes per year and 100 tonnes of mung beans per year (Gorontalo District Agriculture Office, 2018).

The potential very supportive is the cattle population in 2018 amounting to 92,074 heads, with 151 ha of forage land, adequate number of human resources. However, on the other hand, the number of livestock is still far from the need and the availability of beef, the Gorontalo District government will continue to increase the cattle 
population through livestock development programs, more specifically for cattle.

The aim of developing a beef cattle business is to produce meat. The market demand for beef is increasing, supported by a large availability of labor and government policies that support efforts to develop beef cattle. This has not been achieved because farmers often experience difficulties in feeding their livestock during the dry season. On the other hand, the high agricultural production is followed by the production of large waste (straw), but often only burnt. The intensification of the livestock business produces livestock manure, which will cause environmental pollution if not utilized.

Agricultural waste is waste from the production process or by-products obtained during production, if treatment is not carried out, the trash can cause environmental pollution (Rusmono et al., 2007). The potential agricultural waste in the form of straw is an alternative source of feed for livestock that can be utilized. Livestock waste in manure is a very good source of organic fertilizer if managed first (Musnamar, 2005).

The business prospect of integrating livestock crops is where breeders can take advantage of agricultural waste products and livestock waste (livestock manure) can be used as organic fertilizer to increase soil fertility.

The development of the beef cattle business, on the other hand, faces various obstacles, including the unavailability of continuous mass feed. On the other hand, agricultural waste, which is very potential in rice straw and corn waste, can become a source of fibrous feed for cattle farming in line with the increasingly limited land use and area arrangement. For the livestock business, it is not optimal and tends to disturb the environment.

The minimal utilization of agricultural waste from food crops and livestock is caused by the absence of practical efforts to improve market competitiveness. The One alternative is applying a supply chain in which groups of business actors who are interrelated with each other participate in adding value to inputs and turn them into final products needed by consumers (Jain et al., 2010). Beef cattle waste can be used as raw material for making biogas, compost, and burin. The use of the trash can be a source of economic growth for breeders, but this has not been optimally implemented farmer level. Farm's main obstacle is that this business is not integrated with plants, so that feed is not available adequately, especially during the dry season (Muzani et al., 2004). As a consequence, many farmers are forced to sell their livestock even though it is relatively cheap. In efforts to overcome these problems, farmers in several locations in Gorontalo District have implemented an integrated crop-livestock system (CLS), but this has not been done optimally. The main feature of integrating livestock crops is the mutually beneficial bond between the plants and livestock.

Farmers use manure as organic fertilizer for their crops and then use plant waste as animal feed. In simple terms, there is a linkage and nutrient cycle in the livestock plant integration model. The use of cow dung as organic fertilizer can save inorganic fertilizers and increase land productivity. As a consequence, many farmers are forced to sell their livestock even though it is relatively cheap. In efforts to overcome these problems, farmers in several locations in Gorontalo District have implemented an integrated crop-livestock system (CLS), but this has not been done optimally. The main feature of integrating livestock crops is the mutually beneficial bond between the plants and livestock. Farmers use manure as organic fertilizer for their produce and then use plant waste as animal feed. In simple terms, there is a linkage and nutrient cycle in the livestock plant integration model. The use of cow dung as organic fertilizer can save inorganic fertilizers and increase land productivity. 
As a consequence, many farmers are forced to sell their livestock even though it is relatively cheap. Efforts to overcome these problems, farmers in several locations in Gorontalo District have implemented an integrated crop livestock system (CLS), but this has not been done optimally. The main feature of integrating livestock crops is the mutually beneficial bond between the plants and livestock. Farmers use manure as organic fertilizer for their produce and then use plant waste as animal feed. In simple terms, there is a linkage and nutrient cycle in the livestock plant integration model. The use of cow dung as organic fertilizer can save inorganic fertilizers and increase land productivity. In efforts to overcome these problems, farmers in several locations in Gorontalo District have implemented an integrated crop-livestock system (CLS), but this has not been done optimally.

The main feature of integrating livestock crops is the mutually beneficial bond between the plants and livestock. Farmers use manure as organic fertilizer for their produce and then use plant waste as animal feed. In simple terms, there is a linkage and cycle of nutrients in the livestock plant integration model. The use of cow dung as organic fertilizer helped save the use of inorganic fertilizers and increase land productivity. In efforts to overcome these problems, farmers in several locations in Gorontalo District have implemented an integrated crop-livestock system (CLS), but this has not been done optimally. The main characteristic of the integration of livestock crops is the mutually beneficial bond between plants and livestock. Farmers use manure as organic fertilizer for their produce and then use plant waste as animal feed.

In simple terms, there is a linkage and nutrient cycle in the livestock plant integration model. The use of cow dung as organic fertilizer can save inorganic fertilizers and increase land productivity. The main feature of integrating livestock crops is the mutually beneficial bond between the plants and livestock. Farmers use manure as organic fertilizer for their produce and then use plant waste as animal feed. In simple terms, there is a linkage and nutrient cycle in the livestock plant integration model. The use of cow dung as organic fertilizer can save inorganic fertilizers and increase land productivity. The main feature of integrating livestock crops is the mutually beneficial bond between the plants and livestock. Farmers use manure as organic fertilizer for their produce and then use plant waste as animal feed. In simple terms, there is a linkage and nutrient cycle in the livestock plant integration model. The use of cow dung as organic fertilizer can save inorganic fertilizers and increase land productivity.

The development of integrated farming between beef cattle and food crops is an alternative that must be developed so that a design system for producing a beef cattle business with food plants is mutually supportive and can contribute to improving the farmer's economy and sustainably.

\section{MATERIALS AND METHODS}

\section{Time and Location of Research}

The research was conducted in Gorontalo District in three sub-districts, and six villages from April to June 2018. Determining the location of the study was done purposively.

\section{Data Analysis Method}

The method of determining the sample to extract information and knowledge to be studied was chosen deliberately (purpose sampling). The sample selection is adjusted to environmental conditions to represent and understand the problem under study. The sample breeders' determination for the socio-economic survey was carried out by using the purposive sampling method. The data used are primary data and secondary data. Preliminary data obtained from direct observation in the field (word) with the interviews, Focus Group Discussion (FGD), and filling out questionnaires. Secondary data is 
obtained through documentation reports from related agencies.

The data collected is then analyzed using sustainability analysis, modifying the Rap-SISPOTTA Pitcher and Preikshot (2000) method. The measurement of sustainability is based on the economic dimension (economic), the environmental dimension (ecological/environmental), the technical dimension (technical), the institutional dimension (institutional), and the social dimension (sociological). The value of each attribute of each economic, ecological, technological, social, and institutional dimension was analyzed by using Multi Dimental Scaling (MDS) using the Exel for Rap-SISPOTTA application. A feasibility and significance test analysis is carried out through this analytical application, a sustainability analysis, and a sustainability model simulation analysis. (Kavanagh and Picher (2004) in Nantil (2017).

Each dimension has its attributes determined; the number of features for each size depends on the object of sustainability research in the research area. Each point is given an average ordinal scale between 0 and 3. A plate of 0 means bad / less, and a scale of 3 standards good/high. The attributes chosen reflect the level of sustainability in each dimension. They are adjusted to the availability of information obtained from the character of the resources studied in the research area. The number of attributes in this study can in table 1.

Table 1: Number of Attributes for each Dimension of Sustainability

\begin{tabular}{|c|l|c|}
\hline No. & \multicolumn{1}{|c|}{ Dimensions } & Number of Attributes \\
\hline 1 & Ecology & 12 \\
\hline 2 & Economy & 12 \\
\hline 3 & Technology and Infrastructure & 12 \\
\hline 4 & Socio-cultural & 12 \\
\hline 5 & Law and Institutions & 8 \\
\hline \multicolumn{2}{|c|}{ Total } & $\mathbf{5 6}$ \\
\hline \multicolumn{2}{|c|}{ Source: Primary Data, 2018 } \\
\hline
\end{tabular}

The list of attributes used for each dimension is as follows:

\section{A. Ecological Dimensions}

- Utilization of livestock waste for organic fertilizers.

- Utilization of agricultural waste for animal feed.

- Beef cattle raising system

- Land (soil fertility).

- The level of land use for agriculture and livestock.

- Agro-climate.

- Feed carrying capacity.

- Cage hygiene.

- Types of animal feed.

- Land availability for animal feed (grass and corn leaves).

- Livestock waste quantity. 
- The distance from the location of the livestock business to residential areas.

\section{B. Economic Dimension}

- The average livestock income is relative to the UMR in Gorontalo District.

- Average livestock income relative to total revenue.

- Livestock agro-industrial products market.

- Availability of livestock market / livestock business subterminal

- The place where the farmer sells his livestock.

- Contribution to PAD

- Financial feasibility of beef cattle business.

- The amount of subsidy.

- Percentage of poor people.

- Prices of livestock commodities.

- Total agricultural workforce.

- Type of only commodity.

\section{Technology and Infrastructure Dimensions}

- The spread of poskeswan places.

- Artificial insemination service post dissemination (IB)

- Use of vitamins and probiotics to stimulate livestock growth.

- $\quad$ Feed technology.

- Technology for processing livestock waste/livestock agro-industry.

- Technology for processing livestock products.

- Information and transportation technology.

- Availability livestock business facilities and infrastructure.

- Availability of public infrastructure/facilities and infrastructure.

- The level of strengthening livestock cultivation technology.

- Availability of livestock information technology.

- Standardization quality of livestock products.

\section{Socio-Cultural Dimension}

- Work is done individually or in groups. 
- The number of farmer households.

- Knowledge of the environment.

- The absorption rate of labor in the livestock agro-industry.

- Frequency of conflicts related to livestock.

- Family participation in the livestock business.

- The role of the community in animal husbandry.

- Frequency of counseling and training.

- Agricultural labor absorption rate.

- Business alternatives are other than livestock business.

- $\quad$ The number of people working in the livestock agro-industry.

- Allocation of time used for livestock business.

\section{Legal and Institutional Dimensions}

- Farmer-owned training and consultation center.

- Cooperation agreements with other regions regarding animal husbandry.

- Synchronization of central and regional policies.

- $\quad$ Livestock farmer groups.

- Availability of social institutions.

- Microfinance institutions (bank/credit)

- Agricultural extension agencies / BPP

- $\quad$ Area management agency.

The value of each attribute of each economic, ecological, technological, social, and institutional dimension, based on data obtained either through interviews and field observations (primary data) or through literature studies (secondary information), were analyzed by Multi Dimensional Scaling (MDS). Each dimension's entire attribute value is entered in the Microsoft Excel application program, and then analyzed by MDS using the Exel for Rap-Fish application. Through this application, analysis of feasibility and significance tests, sustainable status analysis, and simulation analysis of sustainability models is carried out.

\section{A. Feasibility Test and Significance of the Sustainability Model}

A sustainability model's feasibility test is carried out by measuring the goodness of fit from a distance between the prediction point and the origin through S-stress calculation. The technique used to determine (goodness of fit) is carried out by the least square method, which is based on the root of the euclidean distance (square distance) or the so-called algorithm of scale (Alscal) method, the S-Stress value is calculated based on the following formula: 


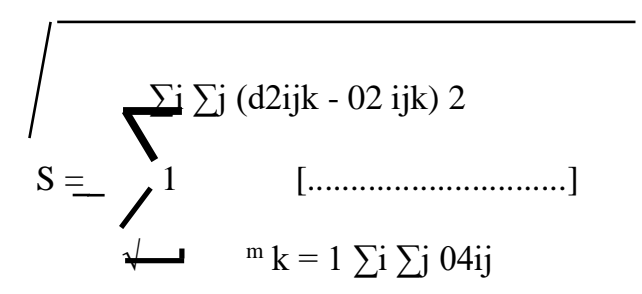

Godness of fit in MDS is a measure of how well it can reflect the original data, determined by the S-Stress value generated from the $\mathrm{S}$ value calculation. The Godness of fit analysis of MDS is determined by the low S-Stress value indicating high Godness of fit, while the high $\mathrm{S}$ value indicates the opposite. In the RAP-SISPOTTA modified from RAPSISPOTTA, a good model shows the stress value is less than 0.25 and vice versa if the stress value is higher than 0.25 , then the MDS result has low accuracy.

Kavanagh and Pitcher (2004) and Pitcher (1999) explain that the Multi Dimensional Scaling (MDS) analysis is then compared with the results of the Monte Carlo (MC) analysis, where the comparison results if the difference is small shows that the impact of scoring errors is relatively small. The effect of several scoring for the attributes is relatively tiny, the assessment with repeated MDS is stable, data errors or data loss are relatively small. Comparing the results of the MC analysis and MDS analysis at the $95 \%$ confidence level or 5\% error rate so that the difference in the value of the study is greater $(\mathrm{MC}-\mathrm{MDS}>5 \%)$ or smaller $(\mathrm{MC}-\mathrm{MDS}<5 \%)$. If the difference between the two analyzes is> 5\%, the MDS analysis results are not sufficient to predict the sustainability index's value. If the difference between the two analyzes is $<5 \%$, the MDS analysis result is enough to predict the sustainability index's value. The modified RAP-SISPOTTA also takes into account the uncertainty aspect and is analyzed using Monte Carlo analysis techniques. Uncertainty is caused by:

- Impact of errors in scoring due to lack of information.

- The impact of the variability in scoring due to differences in ratings.

- $\quad$ Errors in data entry.

- The high-stress value obtained from the ALSCAL algorithm.

Monte Carlo analysis is also a simulation method to evaluate the impact of random errors in the research on each dimension's attributes. Monte Carlo analysis is carried out using a scatter plot method which shows the ordination of each size.

Pitcher and Preikshot, (2001) explain that with the modification of the Rap-SISPOTTA method (Rap-SISPOTTA Modified), the objects observed are based on two to five dimensions so that the ordination technique (distance determination) in MDS is based on Euclidian Distance which is in n dimensions. This study uses five dimensions with the following formula:

$$
\mathrm{d}=\sqrt{ }\{(\mathrm{V} 1-\mathrm{V} 2) 2+\overline{(\mathrm{W} 1-\mathrm{W} 2) 2+(\mathrm{X} 1-\mathrm{X} 2) 2+(\mathrm{Y} 1-\mathrm{Y} 2) 2+(\mathrm{Z} 1-\mathrm{Z} 2) 2\}}
$$

The significance test sustainability model based on the configuration or ordiation of an object or point in the MDS which is approximated by regressing the distance of the Euclidean (j) from point to point $\mathrm{j}$ with the origin ( $\delta y$ ) with the equation:

$$
d_{\mathrm{yes}}=\alpha+\beta \delta \mathrm{ij}+\varepsilon
$$


The distance squared is the weighted Euclidian distance or written as:

$d^{2 \mathrm{ijk}}=\sum \mathrm{a}: \mathrm{r}$ Vka $(\mathrm{Xia}-\mathrm{Xja}) 2$

The determinants of significance from the RAP-SISPOTTA processing with the highest (maximum) Root Means Square (RMS) value up to half the value of each sustainability dimension. Kavanagh and Pitcher (2004) explain that the leveraging factor of significance is an attribute whose existence has a sensitive effect on the increase or decrease in sustainability status. The greater the RMS value, the greater the importance or role of these attributes on the sustainability status's sensitivity.

\section{B. Sustainability Status Assessment}

The method of determining the sustainability status index of the integration of beef cattle business with food crops using the Rap fish technique is based on a predetermined systematic. According to Nababan et al. (2008), determining the index and status of sustainability based on the following stages: 1) assessing the attributes of each dimension of sustainability and assessing these attributes based on actual data through field observations, interviews, discussions with experts, and literature review, 2) attribute score values for each dimension sustainability is then analyzed in the Microsoft Excel program using a template that has been prepared beforehand, so that a value is known as the sustainability index, 3) categorizing the value of the sustainability index based on the sustainability interval to obtain the sustainability status Determination of the index and status of sustainability is based on several stages: 1) Assessment of the overall attributes of each of the dimensions of sustainability in the integration system of beef cattle with food crops is categorized into the categories of good, good enough, poor and bad status. The assumption that performance lies between 0 and $100 \%$ or poor to excellent. Between bad to good scores, there is an interval of performance values, namely adequate and insufficient, so that four levels of performance are obtained, namely bad, poor, moderate and good so that the interval is $0.25 \%, 50 \%$, 75\%, and 100\% (Pitcher and Preikshot, 2001). 1) The assessment of each sustainability dimension's overall attributes in beef cattle's integration system with food crops is categorized into good, good enough, poor, and bad status. The assumption that performance lies between 0 and $100 \%$ or poor to excellent. Between bad to good scores, there is an interval of performance values, namely adequate and insufficient, so that four levels of performance are obtained, namely bad, poor, moderate, and good so that the interval is $0.25 \%, 50 \%$ 75\% and $100 \%$ (Pitcher and Preikshot, 2001). 1) The assessment of each sustainability dimension's overall attributes in beef cattle's integration system with food crops is categorized into good, good enough, poor, and bad status. The assumption that performance lies between 0 and $100 \%$ or poor to excellent. Between bad to good scores, there is an interval of performance values, namely adequate and insufficient, so that four levels of performance are obtained, namely bad, poor, moderate and good, so that the interval is $0.25 \%, 50 \% 75 \%$ and $100 \%$ (Pitcher and Preikshot, 2001).

The results and research on the performance attributes of each dimension are mapped into two reference points which are bad points (bad) and good points (good), and the performance level is divided into 4 (four) categories of attribute research results, as stated by Pitcher (1999). and Kavanagh and Pitcher (2004) in table 2.

Table 2: Sustainability Status Categories

\begin{tabular}{|c|c|l|l|}
\hline No. & Dimension Index Value & Category & \multicolumn{1}{|c|}{ Information } \\
\hline 1 & $00.00-25.99$ & Bad & Not sustainable \\
\hline 2 & $26.00-50.99$ & Less & Less sustainable \\
\hline 3 & $60.00-75.99$ & Enough & Sufficiently sustainable \\
\hline 4 & $76.00-100.00$ & Good & Sustainable \\
\hline \multicolumn{4}{|c|}{ Source: Pitcher (1999), Kavanagh and Pitcher (2004). } \\
\hline
\end{tabular}




\section{RESULTS AND DISCUSSIONS}

The Farmers in Gorontalo District prepare tillage until planting if the rainfall is enough to plant rice; after planting rice, farmers usually grow other crops, such as corn, beans, but some continue to produce rice in the 2nd planting season according to the cropping pattern. Based on the hydrological aspect, natural water sources in Gorontalo District come from rain, springs, lakes and rivers. Meanwhile, most of the land area is used for productive activities from the part of land use. Dryland is used for dryland/gardens, fields / Huma, plantations, and cultivated forest with a larger land area than wetland for rice fields. In addition to land for rice fields, the existing land can be used as a forage producer for beef cattle,

Forage sources other than field grass, which is the dominant land used by breeders. Forage from food crop and plantation waste can also be used as beef cattle feed, such as rice straw, corn straw, peanut straw, soybean straw, cassava leaves, sweet potato leaves, and sugar cane shoots.

Food crop waste as a by-product of harvested agricultural products can be used as ruminant feed to sustain life, especially during the dry season. Utilization of food crop waste as animal feed is a form of synergy to increase agricultural production, livestock and improve environmental quality. The potential for agricultural destruction in Gorontalo District on the map of the distribution of food crop production.

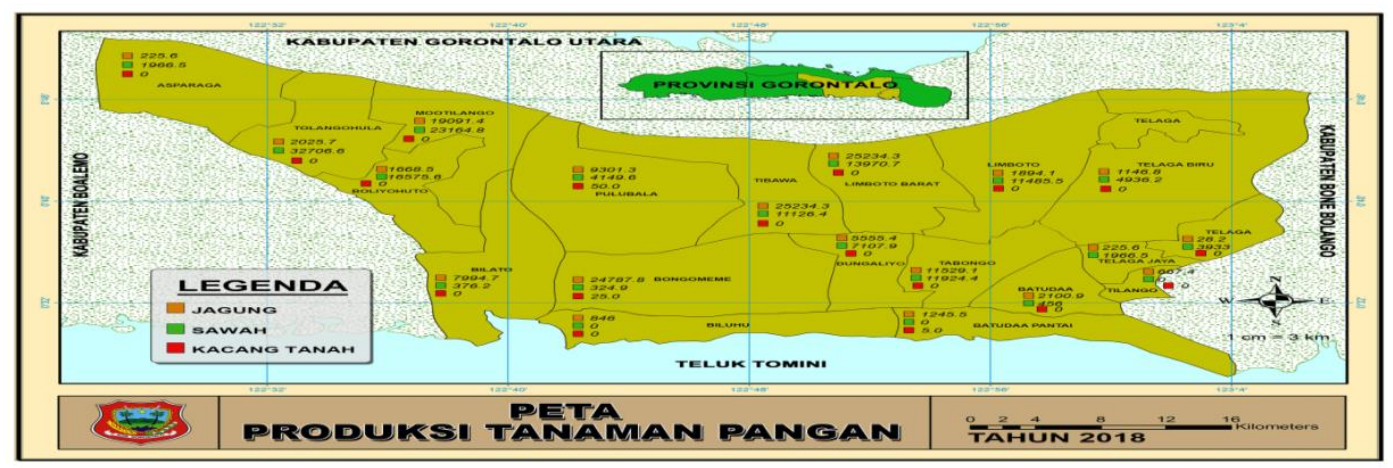

Figure 1: Map of the Distribution of Food Crops in Gorontalo District in 2018.

The highest distribution of food crop production is in Tolanghula District. This shows that food crop production can produce waste that can be used as animal feed.

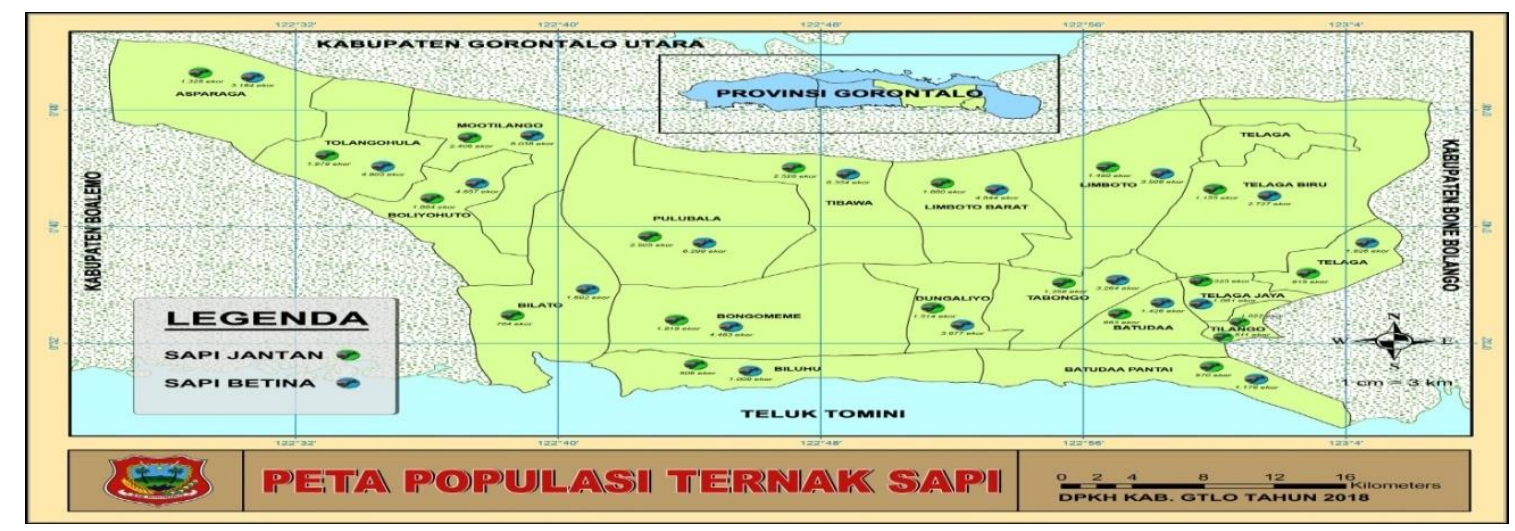

Figure 2: Map of the Distribution of Cattle Population in Gorontalo District in 2018.

The distribution of beef cattle population in Gorontalo District shows that the highest population is in Tibawa 
District. This indicates that the need for feed in this district will be more. This data is very important to know the demand for animal feed in each region.

\section{A. Availability of Feed}

Table 3: Feed Production for Beef Cattle in Gorontalo District 2018

\begin{tabular}{|c|c|c|c|c|c|}
\hline \multirow{3}{*}{ Districts } & \multicolumn{4}{|c|}{ Feed Production (Tonnes BK / Year) } & \multirow{3}{*}{$\begin{array}{c}\text { Total } \\
\text { (Tonnes BK / } \\
\text { Year) }\end{array}$} \\
\hline & \multicolumn{2}{|c|}{ Source of Forage } & \multirow{2}{*}{$\begin{array}{c}\text { Forage } \\
\text { Feed }\end{array}$} & \multirow[b]{2}{*}{ Concentrate } & \\
\hline & $\begin{array}{l}\text { Forage } \\
\text { Natural }\end{array}$ & $\begin{array}{c}\text { Waste } \\
\text { Agriculture }\end{array}$ & & & \\
\hline Blue Lake & 10,019 & 16,926 & 26,945 & 1,306 & 28,251 \\
\hline Pulubala & 29,794 & 73,982 & 103,776 & 138 & 103,914 \\
\hline Boliyohuto & 2,813 & 25,665 & 28,478 & 3,920 & 32,398 \\
\hline
\end{tabular}

The results of the analysis of feed production show that Pulubala district has the greatest potential for forage, which is equal to 103 thousand tonnes BK/year. In contrast, the sub-district that has the greatest potential for concentrate is Boliyohuto.

Agricultural waste is very potential to be used; as feed because it has several advantages. Namely is available continuously in large volumes widespread, does not compete with humans, is safe for livestock health and livestock products, responsive to livestock production, easy in the process of collection, storage, and transportation. The price is low. These food plants' side products are rice straw, corn straw, soybean straw, peanut straw, cassava leaves, sugarcane leaves, etc. These various types and advantages should be used as an opportunity to optimize the use of agricultural waste as beef feed.

\section{B. Beef Cattle Business Integration with Food Crops}

Sumarno (2006) argues that there are direct and indirect relationships and reciprocal and causal relationships in a model. Model is an abstraction or simplification of an object, activity, or actual reality.

There are three patterns of forming an integration system: first, an integration system that occurs independently or independently, which generally happens by evolution. In this condition, the farmers initially maintain one of the integration components, followed by integration of crops with livestock in land division. The second, the integration system, occurs because of program support or promotion from the government. It is supported by financial assistance that can develop by accelerating the evolution process through the integration component or technology assistance. Third, there is a development of integration by utilizing the waste components of the integration system. Farming components that are integrated must synergize with each other to achieve optimal production. Food crop farming, Plantation and horticulture can provide feedstock for ruminants.

In contrast, livestock can provide raw materials for organic fertilizers as sources of nutrients that plants need and provide basic materials for renewable energy (biogas) for human benefit. The integration of ruminants with other farms is also a major way of intensifying agriculture. However, livestock is still a supporting and complementary component, not a major part in the livestock-integration system.

The study was conducted in Gorontalo District, involved 100 farmers as respondents consisting of five farming patterns, namely: 1) Cattle - Rice (SP), 2) Cattle - Rice - Corn (SPJ) farming patterns, 3) Cattle farming patterns. - Rice Beans (SPK), 4) Cattle - Corn (SJ) planting patterns, and 5) Cattle - Corn - Beans (SJK) farming patterns. Respondent age 
based on the farming pattern.

Currently, livestock and crop businesses are still being cultivated in a diversified manner. They have not been implemented in an integrated farming manner. An integrated crop-beef cattle system (SISPOTTA) is needed, a farming system that incorporates beef cattle business with food crops and related components in an integrated manner. Livestock system) can be used as a consideration for program formulation to be applied at the regional level of cattle breeders to develop sustainable livestock. Some of the problems that exist in the research area, namely the integration model, have begun to be applied but are still constrained by the factors that affect the performance of each production component, both beef cattle, plants, waste, biogas, organic fertilizers,

\section{Sustainability Analysis}

Analysis of the sustainability status needs to be carried out to determine the conditions at the level of sustainability status in the integrated system of food crop farming and beef cattle business in a place. The story of sustainability of the integrated food crop farming and beef cattle business in the research area is analyzed using the MDS method using RapSISPOTTA. The analysis uses five different dimensions or aspects of sustainability (sustainable metric) to measure the sustainability of livestock farming, namely: ecological sizes (12 attributes), technological dimensions (12 points), economic dimensions (12 points), socio-cultural dimensions (12 details), and legal dimensions (8 features). Summary of results from MDS - Rap-SISPOTTA for the five dimensions can be presented in table 4 as follows:

Table 4: Summary of MDS Analysis Results - Rap-SISPOTTA

\begin{tabular}{|l|c|c|c|}
\hline \multicolumn{1}{|c|}{ Dimensions } & Stress & R-Square & Iteration \\
\hline Ecology & 0.0109 & 0.9770 & 2 \\
\hline Technology & 0.0184 & 0.9859 & 2 \\
\hline Economy & 0.0158 & 0.9977 & 2 \\
\hline Socio-cultural & 0.0026 & 0.9893 & 2 \\
\hline Law & 0.0158 & 0.9838 & 2 \\
\hline Source: Data processed, 2020 \\
\hline
\end{tabular}

The combination of the relationships of the five dimensions used to measure business sustainability in the integrated system of beef cattle and food crops in the study area is shown in figure 3.

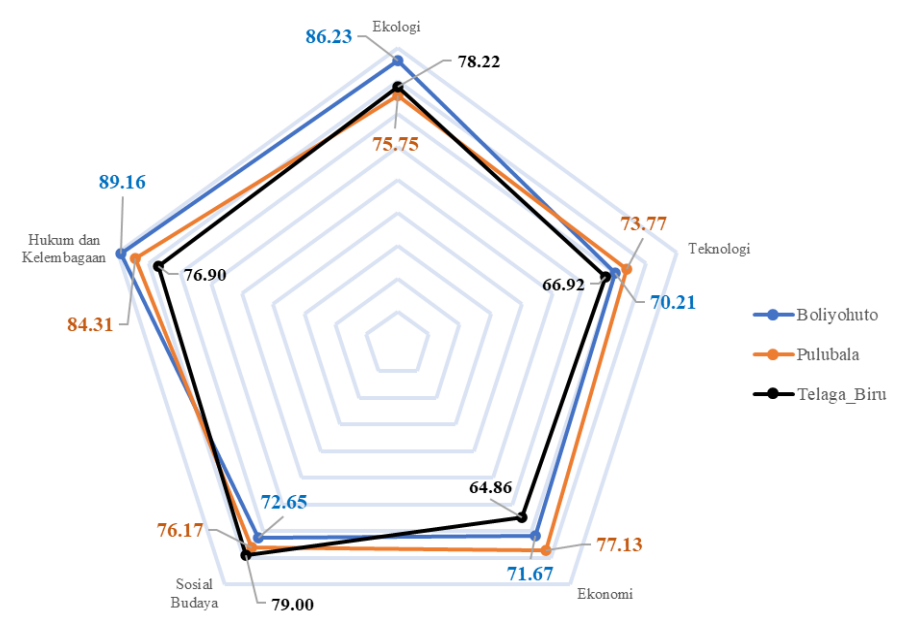

Figure 3: Radar Diagram of the Sustainability Status of the Beef Cattle Business Integration Model and Food Crops.

The average of the sustainability index for the integration of beef cattle and food plants in the study area, namely 
Pulubala and Boliyohuto, is 77.43 and 77.98 or is in the range of 75-100 which means that it is 'good sustainable', while the Telaga Biru area is equal to 73.18 or in the field 50-74.99 which means 'quite sustainable'. The analysis results also show that of the five existing dimensions, the dimension that has a poor sustainability index value is the technology dimension.

The reference used as a basis for determining the goodness of the analysis results (Goodness-of-fit) in MDS is the stress value less than 0.25 and the R-square approaching 1.00, it can be said that the MDS analysis meets the Goodness-offit criteria so that worthy of further discussion or comment.

\section{CONCLUSIONS}

Based on the description of the results and discussion, several conclusions were obtained, namely:

- Resources owned by farmers make it possible to cultivate integrated crop and livestock farming. The farming pattern applied to incorporate plants and livestock is rice farming - corn $2.12 \mathrm{ha}$.

- Based on the allocation of land, labor, capital, availability of feed, and livestock's ability to provide compost and economically, an integration model that can be developed is rice-corn-livestock integration.

- The choice of forage composition comes from natural grass and in the dry season the forage comes from fermented straw. The design of feed for the rice-livestock integration model, namely $70 \%$ forage grass and $30 \%$ waste provides a higher income.

\section{REFERENCES}

1. Diwyanto, KBR Prawiradiputra, and D. Lubis. 2002. Integration of crops - livestock in competitive, sustainable and democratic agribusiness, Bulletin of Indonesian Animal Science, Wartazoa. Volume 12 Number 1: Center for Animal Research and Development, Bogor.

2. Jain. J., Dangayach, GS, Agarwal, G., and Banerjee, S., 2010. Supply chain management: Literature review and some issues, Journal of Studies on Manufacturing 1 (1), 11-25.

3. Kavanagh, P and TJ Pitcher, 2004. Implementing Microsoft Excel Software for Rapfish: A Technique for The Rapid Appraisal of Fisheries Status. University of British Columbia. Fisheries Center Research Reports 12 (2).

4. Musnamar, EI 2005. Solid Organic Fertilizers: Manufacture and Application, Self-Help Publishers, Jakarta.

5. Muzani A., YG Bulu, K. Puspadi, and TS Penjaitan, 2004 Potential of Feed in a Plant-Livestock Integration System in Lombok, West Nusa Tenggara. Proceedings of the Workshop on Plant-Animal Farming Systems and Institutions. Agricultural Research and Development Agency. Jakarta.

6. Nantil B. 2017, Optimization of Beef Cattle Business with Food Crop Farming in Sustainable Rice Fields in Jember Regency, Doctoral Dissertation Program, Brawijaya University, Malang.

7. Pasandaran E., 2006. Alternative Policies to Control Irrigated Paddy Land Conversion in Indonesia. Journal of Agricultural Research and Development 25 (4): 123 - 129.

8. Pitcher, TJ and D. Preikshot. 2001. Rapfish: A Rapid Appraisal Technique to Evaluate The Sustainability Status of Fisheries. Fisheries Research 49 (2001): 255-270.

9. Priyanti, A and A Djajanegara. 2004. Development of integrated beef cattle business. Proceedings of the National Workshop on Beef Cows: Strategy for developing beef cattle with an agribusiness and sustainable approach, Yogyakarta 8-9 October 2004. Center for Animal Husbandry Research and Development, Bogor. 
10. Rao, N. and Rogers, P, 2006. Assessment of Agricultural Sustainability, Current Science. 91 (41)

11. Rusmono, M, Rochaman M, Nuraeni I, Maryani A, 2007. Utilization of Agricultural Waste. Open University Publisher. Jakarta.

12. Subagyono. 2004. Prospects for Integrated Animal Development in Plantation Areas. Proceedings of the National Seminar on Plant - Animal Integration System. Denpasar 20-22 July 2004. Animal Husbandry Research and Development Center, Bali Province Agricultural Technology Research Center and Crop - Animal System Research Network (CASREN), Bogor.

13. Sumarno, 2006. Sustainable Rice Production System by Implementing a Sustainable Green Revolution, Book I of the Proceedings of the National Seminar on Agricultural Land Resources, Bogor, 14-15 September 2006

14. Suyitman, SH Sucahyo, C. Herison, and Muladno, 2009, Status of the Sustainability of Animal-Based Areas in Situbondo Regency for the Development of an Agropolitan Area. Journal of Agro Economics 27 (2): 165-169 
